\title{
Drugs against pain-new concepts
}

\author{
Paraskeyi Papaioannidou \\ From $1^{\text {st }}$ International Congress on Neurobiology and Clinical Psychopharmacology and European \\ Psychiatric Association Conference on Treatment Guidance \\ Thessaloniki, Greece. 19-22 November 2009
}

Non Steroid Anti-Inflammatory Drugs (NSAIDs) have been the treatment of choice for mild to moderate inflammatory pain for more than a century. NSAIDs block the formation of prostaglandins by inhibiting cyclooxygenase (COX). Their most common side-effect is ulceration of the upper gastrointestinal tract. The development of selective COX-2 inhibitors (coxibs) has reduced gastrointestinal toxicity significantly, but coxibs appear to have a significant cardiovascular risk and to be less effective in neuropathic pain.

Opioids have traditionally been used for severe acute and cancer chronic pain, while recently their use in the therapy of chronic non-cancer pain has increased substantially. Chronic opioid therapy can be an effective treatment for carefully selected and monitored patients with chronic non-cancer pain. However, opioids are also associated with potentially serious harm, including opioid-related adverse effects and outcomes related to the abuse potential of opioids.

Many drugs that are used to treat other illnesses can also be used for the treatment of chronic and neuropathic pain, either alone or in combination with other analgesics. These drugs include antidepressants, anticonvulsants, antimigraine medicines, local anesthetics, corticosteroids, muscle relaxants, benzodiazepines, neuroleptics, cannabinoids, antihistamines, $\alpha 2$ adrenergic agonists, stimulants, biphosphonates and calcitonin, as well as tramadol, which is a weak $\mu$-opioid agonist that inhibits the reuptake of norepinephrine and serotonin, too.

Recently, novel targets against inflammatory pain with improved specificity and fewer side-effects are under investigation, like prostaglandin E synthases, prostaglandin receptors, COX-inhibiting nitric oxide donators (CINODs), downregulation of inflammatory transcription factors and cytokines, and downstream effectors of

\footnotetext{
1st Department of Pharmacology, School of Medicine, Aristotle University of
} Thessaloniki, Greece prostaglandins in the PNS and CNS. New targets against chronic inflammatory and neuropathic pain include modulators of nociception and pain transmission, like NMDA and other glutamate receptors, GBP and voltage-gated $\mathrm{Ca} 2+$ channels (VGCC), nicotinic acetylcholine receptors, transient receptor potential (TRP) channels, tetrodotoxin-resistant $\mathrm{Na}+$ channels, inhibitory glycine and GABA receptors, monoamine receptors, adenosine receptors, neuropeptide $Y$ receptors, neurotensin receptors, as well as regulators of inflammation, neuroinflammation and pain, like nerve growth factor (NGF), matrix metalloproteases, neuropeptide $S$, substance $\mathrm{P}$, neuromedin $\mathrm{U}$, somatostatin and other neuropeptides.

Published: 22 April 2010

doi:10.1186/1744-859X-9-S1-S4

Cite this article as: Papaioannidou: Drugs against pain-new concepts. Annals of General Psychiatry 2010 9(Suppl 1):S4.

\section{Submit your next manuscript to BioMed Central and take full advantage of: \\ - Convenient online submission \\ - Thorough peer review \\ - No space constraints or color figure charges \\ - Immediate publication on acceptance \\ - Inclusion in PubMed, CAS, Scopus and Google Scholar \\ - Research which is freely available for redistribution \\ Submit your manuscript at www.biomedcentral.com/submit}

